\title{
Alternate livelihood development for 'Aila' affected tribal people through aquaculture in Bali Island of the Sunderban, West Bengal, India
}

\author{
P. P. CHAKRABARTI, A. GHOSH, B. C. MOHAPATRA, N. K. BARIK, A. DAS, \\ K. KUMAR, S. C. MONDAL, D. MAJHI, A. MISTRY AND P. JAYASANKAR \\ ICAR-Central Institute of Freshwater Aquaculture, Kausalyaganga, Bhubaneswar - 751 002, Odisha, India \\ e-mail:ppcifa09@gmail.com
}

\begin{abstract}
Bali Island is one of the mangrove reclaimed zone of Sunderban, West Bengal, inhabited mostly by tribal communities. Lack of employment opportunities and limited access to market as well as urban areas are characteristic features of livelihood of the people. The devastating cyclone "Aila" which hit the island during 2009, resulted in ingress of saline water, degradation of land and water resources, loss of biodiversity, destruction of animal and farm infrastructure which further led to major loss to the livelihood system. Aimed at restoring livelihood of these tribal people, aquaculture based interventions were initiated by the ICAR-Central Institute of Freshwater Aquaculture (ICAR-CIFA), Bhubaneswar, during the period 2013-14 among 51 tribal families in Bali Island. The interventions were effected by creation of alternative livelihood options through composite fish culture (single component), fish-cum-duck culture (multi-component) and hatchery production of fish seed (single component). Scientific management of the aquaculture ponds helped to achieve an average fish production of $4-6 \mathrm{tha}^{-1} \mathrm{yr}^{-1}$ from a benchmark of around $1 \mathrm{t} \mathrm{ha}^{-1} \mathrm{yr}^{-1}$. One lakh fingerlings of Labeo rohita and L. bata were also produced through FRP carp hatchery. In addition, fish-cum-duck farming trials also created nutritional security through egg, duck meat and fish production. The economic impact assessment revealed that investment of ₹11.05 lakhs by ICAR-CIFA, resulted in a net incremental wealth generation of ₹20.67 lakhs. For a typical tribal family of average 5 members, $67 \%$ alternative livelihood support was achieved through duck-cum-fish farming.
\end{abstract}

Keywords: Aquaculture, Bali Island, Carps, Livelihood, Sunderban

\section{Introduction}

Bali Island is one of the mangrove reclaimed zone of Sunderban $\left(21.94^{\circ} \mathrm{N}-22.30^{\circ} \mathrm{N} ; 89.00^{\circ} \mathrm{E}-89.55^{\circ} \mathrm{E}\right)$ resided by tribal, scheduled caste and other communities. It is a small Island in Indian Sunderban Archipelago, which falls under the jurisdiction of Gosaba Block in South 24 Parganas District of West Bengal. Geographically, Sunderban (both India and Bangladesh part) is the largest single mangrove area of the world, situated in the estuary of Ganga-Brahamaputra delta facing the Bay of Bengal. Indian Sunderban covers 9630 sq. km area (HDRCC, 2009). It has around 102 small and large islands, out of which, 54 are inhabited by human beings (HDRCC, 2009). This unique deltaic island comprises both mangrove covered forest areas and forest reclaimed zone.

Bali Island is inhabited by people surviving against poverty, limited livelihood options, malnutrition, lack of proper education and frequent tiger attack. Bali appears to be remote in terms of commuting; the only means is waterway and boats are the only convenient transport for connection with the mainland. People of this deltaic island mostly depend on the forest for their livelihoods due to lack of employment opportunities and poor knowledge on agriculture/aquaculture.
This in turn expose them to frequent attack of tiger. The mangrove forest is commercially exploited, particularly for the Non-Timber Forest Produce (NTFP) like honey, which is one of the epitomes for the livelihoods of many forest fringe dwellers (Bhattacharya, 2004). Some of the earlier studies focused on ecology of the region (Chaudhuri and Chaudhury, 1994; Bhattacharya, 1998; Hazra, 1999; Bhattacharya et al., 2001; Chattopadhyay, 2003; Chaudhury, 2007). Fishing also plays a significant role in the socio-economy of the Sundarban communities. However, overexploitation and population pressure has resulted in sharp decline of fish catch in these areas. Moreover they often face tiger attack during fishing in the core area of the Sundarbans.

Sunderban is vulnerable to natural calamities like cyclonic storm, strong sea wind, high sea surges, tsunami and soil erosion. In 2009, the strong cyclonic storm 'Aila', which hit the coast, virtually washed out the entire Sunderban region. The devastating storm caused very high human casualties, destroyed a major portion of livestock population and made large number of people homeless. The impact of the cyclone in Bali Island was very severe, as all types of water bodies i.e., small, medium and large ponds, canals and paddy fields were flooded with saline water due to ingress 
of seawater and subsequent overflow of river banks. This resulted in extensive loss of indigenous freshwater fish diversity including carps which serve as the major source of protein as well as livelihood of the populace. With the objective of providing alternate livelihood avenues for the cyclone affected tribal population, the ICAR-Central Institute of Freshwater Aquaculture (ICAR-CIFA), Bhubaneswar initiated a programme on aquaculture based interventions among selected households in the island during 2013-14. The present study was undertaken with the objective to raise their livelihood through aquaculture as an alternative livelihood option and to evaluate technical and economic feasibility of aquaculture based livelihood system in the island.

\section{Materials and methods}

\section{Study area}

The study was conducted during March 2013 to April 2014, among 51 tribal families inhabiting Adivasipara in Bali Island of the Sundarbans covering a total of 4.29 ha water bodies. Among them, 13 families were selected exclusively for composite fish culture (CP, single component), 1 family for fish seed production (SP, single component) and 38 families for both composite fish culture and duck farming $(\mathrm{CP}+\mathrm{DP}$, multi-component). Three families were also identified for traditional fish culture practice (TP, control ponds) for comparison with composite fish culture (demonstration ponds). Participatory Rural Appraisal (PRA) technique was used in the Bali-II block to get primary data on the resources, livelihood systems, marketing and other aspects relevant to aquaculture.

\section{Composite fish culture (single component)}

Farmers having small ponds with mean water area of $0.1 \pm 0.03$ ha were selected for composite fish culture. In ponds where dewatering was not possible, unwanted fish were eliminated by repeated netting and aquatic weeds were removed manually. In other ponds, pond water was discharged to nearby canals as pre-stocking measure and filled with the same canal water employing diesel operated pump. A water depth of around $1 \mathrm{~m}$ was maintained in each pond. Inorganic fertilisers, urea and single super phosphate (SSP) were applied@ 5 and $12.5 \mathrm{~kg} \mathrm{ha}^{-1}$ respectively; whereas cow dung was applied as organic manure @ $400 \mathrm{~kg} \mathrm{ha}^{-1}$ at fortnightly intervals. $\mathrm{pH}$ of the water was maintained within an ideal range of 7-8 through periodical use of agricultural limestone (a) $500 \mathrm{~kg} \mathrm{ha}^{-1} \mathrm{yr}^{-1}$. The control ponds (TP) were prepared by applying raw cow dung as organic manure. No lime and inorganic fertilisers were applied.

Advanced fingerlings of Indian major carps (rohu Labeo rohita, catla Catla catla, mrigal Cirrhinus mrigala) and minor carp (bata Labeo bata) having weight/length of $35 \mathrm{~g} / 15 \mathrm{~cm}, 70 \mathrm{~g} / 17 \mathrm{~cm}, 80 \mathrm{~g} / 19 \mathrm{~cm}$ and $20 \mathrm{~g} / 11 \mathrm{~cm}$ respectively were stocked in all the ponds at a stocking rate of 10,000 nos. ha- ${ }^{-1}$ in two phases at 3:2:2:3 ratio for rohu: catla: mrigal: bata. The advanced fingerlings were procured from Naihati fish seed market and transported to the experimental site with oxygen packing.

Feeding was done with sinking pellet fish feed @ 2\% of total body weight for initial 7 months (March-September), @ $1 \%$ up to subsequent 4 months (October-January) and @ $2 \%$ in the last month (February). Fish were sampled monthly and weighed to calculate the fish biomass and accordingly, the daily ration was adjusted for the subsequent month. The commercial pellet feed used had moisture $12 \%$ (max.), crude protein $28 \%$ (min.), crude fiber $10 \%$ (max.), crude lipid $4 \%$ (min.) and acid insoluble ash 4\% (max.) with digestible energy of $3000 \mathrm{k} \mathrm{cal} \mathrm{kg}^{-1}$ feed (min.). In control ponds, kitchen waste was provided instead of formulated feed.

Water quality analyses were done at monthly intervals for parameters viz., dissolved oxygen (DO), alkalinity, hardness and phosphate following APHA (1998). Water temperature and $\mathrm{pH}$ were measured using digital meter (Eutech).

\section{Duck-farming and composite fish culture (multi-component)}

Farmers having small ponds with mean water area of $0.078 \pm 0.008$ ha were selected for duck-cum-fish culture. A total of 800 nos. of ducklings (one month old) of Khaki Campbell breed (Anas platyrhynchos) were distributed at the rate of 25 nos. among 8 beneficiaries and 20 nos. among 30 beneficiaries for duck-cum-fish culture. A low cost duck house was provided to each farmer along with feeding and water trays. Duck feed was purchased from West Bengal Dairy and Poultry Development Corporation Ltd. and provided for initial 3 months of rearing. The households fed the ducks for the rest of the growing period with farm made feed prepared from locally available ingredients. Vaccination of duck for polio and cholera diseases was done at the $4^{\text {th }}$ and $6^{\text {th }}$ week. Pond management and stocking of fish was done as per standard protocols followed in composite fish culture practices. However, no fertilisers like urea, SSP and raw cow dung were applied.

\section{Fish seed production (single component)}

For breeding purpose, brooders of age two years (rohu and bata) weighing a total of $40 \mathrm{~kg}$ were obtained from different ponds in Bali Village and reared for 15 days in a pond (adjacent to the hatchery unit), having 0.05 ha water spread area and $1 \mathrm{~m}$ average depth. The fish were fed @ $2-3 \%$ of body weight with locally available groundnut oil cake and rice bran in 1:1 ratio. For spawn production, one unit of portable FRP carp hatchery (ICAR-CIFA) consisting of four parts i.e., one breeding pool, one hatching pool, one egg/spawn collection tank and one plastic overhead tank of 
20001 capacity was installed. The breeding pool is cylindrovertical in shape with $2.15 \mathrm{~m}$ dia, $0.9 \mathrm{~m}$ height, $1: 22$ bottom slope and 34091 water holding capacity. The flow rate during egg collection was maintained at 1-1.5 $1 \mathrm{sec}^{-1}$. One shower was provided at the top of the pool for better aeration. Hatching of fertilised eggs was completed in one operation in the hatching pool of $1.4 \mathrm{~m}$ dia, $0.98 \mathrm{~m}$ height, 14001 total volume and 12001 net egg incubation volume with a FRP inner chamber. The flow rate during operation was maintained at $0.3-0.41 \mathrm{sec}^{-1}$. The incubation pool had capacity of hatching 1 million eggs per operation. Water level in the rectangular egg/spawn collection tank $(1.0 \times 0.5 \times 0.5 \mathrm{~m}$; having water holding capacity $250 \mathrm{l}$ ) was maintained at a height of $0.45 \mathrm{~m}$ during operation. Cotton inner hapa was fixed inside the collection tank to collect egg/spawn from breeding/incubation pool, respectively. A pump set (1 HP) was used to fill the storage tank periodically to supply water to hatchery continuously.

On 26 August 2013, male and female brooders of L. rohita and L. bata were caught from the brood pond early in the morning, transported to the hatchery in hammock and conditioned for $1 \mathrm{~h}$ in the breeding pool prior to administration of inducing agent, Wova-FH @ $0.5 \mathrm{ml} \mathrm{kg}^{-1}$ body weight to female and $0.2 \mathrm{ml} \mathrm{kg}^{-1}$ body weight to male. In case of L. rohita, three females and five males having total weight of 3.3 and $4.8 \mathrm{~kg}$, respectively were injected with hormone and released into the breeding pool whereas in case of $L$. bata hormone administration was done in ten females and twelve males having total weight of 2.5 and $2.15 \mathrm{~kg}$, respectively. Normal hatchery operation practices were followed for production of carp seed (Mohapatra et al., 2005, 2007, 2008). Six hours post-injection, 6 lakh fertilised eggs were collected in the hapa of the collection tank and were released into the hatching pool for incubation. Water temperature of the hatching pool varied from $30.4-33.3^{\circ} \mathrm{C}, \mathrm{pH}$ 7.2-7.6, alkalinity $100-110 \mathrm{mg} \mathrm{l}^{-1}$ and hardness $90-100 \mathrm{mg} \mathrm{l}^{-1}$ during entire operation period. After hatching, water circulation in the pool was maintained as per standard protocol (Mohanty et al., 2009) for the next three days and the pool was disinfected by sprinkling $5 \mathrm{ppm}$ potassium permanganate solution at an interval of every two hours. After $72 \mathrm{~h}$ of egg hatching, 5 lakh spawn was collected from the hatching pool of the spawn collection tank.

Four earthen rearing ponds of 0.02 ha each were selected and prepared for advance fingerlings production. Stocking was done@6 million spawn ha ${ }^{-1}$ and reared for 90 days for fingerling production by following the standard practice of seed rearing (CIFA, 2004).

\section{Results and discussion}

\section{PRA survey}

People in the study area are acquainted with traditional fish culture in ponds and fishing in canals and paddy fields. For the seed materials, they are mostly dependent on vendors and do not follow any specific stocking density, species ratio and stocking size. Due to non-availability of quality fish seed, lack of information about pond fertilisation, fish feed and feeding schedule, the average productivity in ponds was reported to be low (800-1000 kg ha-1 $\mathrm{yr}^{-1}$ ) (Chakrabarti et al., 2013). There is no irrigation system available in this area, so rainwater is the only source for fish culture. The poor socio-economic conditions, lack of adequate livelihood opportunities and vulnerability to natural calamities, lack of ready market for the inputs and outputs, are some of the factors that highlight the need for alternative livelihood options for the people residing in the island (Chakrabarti et al., 2013).

\section{Water quality parameters}

Water quality parameters of ponds selected for the study were found ideal and suitable for carp grow-out culture (Bag, 2014). Temperature ranged between $24-34^{\circ} \mathrm{C}$ during the culture period except during November-January. However, wide variations in water hardness were recorded during the culture period (Table 1).

Table 1. Water quality parameters of the ponds during the culture period

\begin{tabular}{lll}
\hline Parameter & $\begin{array}{l}\text { Traditional } \\
\text { practice }\end{array}$ & $\begin{array}{l}\text { Composite } \\
\text { culture }\end{array}$ \\
\hline Temperature $\left({ }^{0} \mathrm{C}\right)$ & $24-34$ & $24-34$ \\
$\mathrm{pH}$ & $6.5-7.5$ & $7-8$ \\
$\mathrm{DO}\left(\mathrm{mg} \mathrm{l}^{-1}\right)$ & $4-6$ & $5-7$ \\
Alkalinity $\left(\mathrm{mg} \mathrm{l}^{-1}\right)$ & $70-110$ & $85-120$ \\
Hardness $\left(\mathrm{mg} \mathrm{l}^{-1}\right)$ & $135-286$ & $115-255$ \\
Available phosphorus $\left(\mathrm{mg} \mathrm{l}^{-1}\right)$ & $0.01-0.2$ & $0.02-0.05$ \\
\hline
\end{tabular}

\section{Composite fish culture (single component)}

Results of the study indicated that fish growth in the traditional fish ponds was much lower compared to the demonstration ponds due to lack of pond fertility management and feeding. Although there was no significant difference between the initial weights of individual species stocked in the traditional ponds (TP) and demonstrated ponds (CP), the average body weight gain and the specific growth rate of all fish species reared in the demonstrated ponds for one year was found to be significantly high $(\mathrm{p}<0.05)$ compared to the fish cultured in the traditional ponds (Table 2).

Total fish production was $5.966 \mathrm{t}$ from 13 beneficiaries' ponds (CP) with mean water area of $0.1 \pm 0.03$ ha registering a mean productivity of $4.683 \pm 0.13 \mathrm{tha}^{-1} \mathrm{yr}^{-1}(\mathrm{n}=13)$, whereas in the traditional ponds (TP), the mean productivity was $0.975 \pm 0.01 \mathrm{t} \mathrm{ha}^{-1} \mathrm{yr}^{-1}(\mathrm{n}=13)$ (Table 3). At stocking, there was no significant difference in mean body weight of different 
Table 2. Growth performance of fish in the culture ponds during 2013-14

\begin{tabular}{llllll}
\hline Fish species & Treatment & Initial weight $\left(\mathrm{g} \mathrm{fish}^{-1}\right)$ & Final weight $\left(\mathrm{g} \mathrm{fish}^{-1}\right)$ & Avg. weight gain $(\mathrm{g})$ & Specific growth rate \\
\hline L. rohita & TP & $35.6 \pm 0.7$ & $243.3 \pm 6.0$ & $207.7 \pm 5.4$ & $0.53 \pm 0.002$ \\
& CP & $33.4 \pm 0.6$ & $533.4 \pm 5.7$ & $500.0 \pm 5.8$ & $0.76 \pm 0.006$ \\
C. catla & TP & $72 \pm 3.5$ & $345.3 \pm 7.2$ & $273.3 \pm 6.2$ & $0.4 \pm 0.01$ \\
& CP & $70.05 \pm 1.2$ & $638.2 \pm 11.1$ & $568.1 \pm 11.1$ & $0.60 \pm 0.006$ \\
C. rigala & TP & $81 \pm 1$ & $269 \pm 4.9$ & $188 \pm 5.1$ & $0.33 \pm 0.006$ \\
& CP & $82.2 \pm 1.3$ & $571.1 \pm 22.7$ & $488.9 \pm 23.2$ & $0.52 \pm 0.024$ \\
L. bata & TP & $20.3 \pm 1.5$ & $105.7 \pm 5.2$ & $85.3 \pm 5.6$ & $0.45 \pm 0.024$ \\
& CP & $20.4 \pm 0.7$ & $193.4 \pm 2.5$ & $173.04 \pm 2.7$ & $0.619 \pm 0.009$ \\
\hline
\end{tabular}

Data expressed as mean \pm S.E.; $n=3$ for $\mathrm{TP}$ and $\mathrm{n}=13$ for $\mathrm{CP}$

Table 3. Details of traditional practice (TP), composite fish culture (CP) and composite fish culture + duck farming practice $(\mathrm{CP}+\mathrm{DP})$ demonstrated during 2013-14

\begin{tabular}{llll}
\hline Particulars & $\mathrm{TP}(\mathrm{n}=3)$ & $\mathrm{CP}(\mathrm{n}=13)$ & $\mathrm{CP}+\mathrm{DP}(\mathrm{n}=38)$ \\
\hline Number of units & 3 & 13 & 38 \\
Total area covered $(\mathrm{ha})$ & 0.3 & 1.331 & 2.963 \\
Mean area (ha) & $0.1 \pm 0.017$ & $0.1 \pm 0.03$ & $0.08 \pm 0.008$ \\
Total fish production $(\mathrm{kg})$ & 293 & 5966 & 13947 \\
Total fish feed applied $(\mathrm{kg})$ & 0 & 5475 & 13024 \\
Mean fish production $(\mathrm{kg})$ & $98 \pm 17$ & $459 \pm 142$ & $367 \pm 38$ \\
Overall fish productivity $\left(\mathrm{kg} \mathrm{ha}^{-1}\right)$ & 977 & 4483 & 4707 \\
Mean fish productivity $\left.(\mathrm{kg} \mathrm{ha})^{-1}\right)$ & $975 \pm 13$ & $4683 \pm 129$ & $4840 \pm 85$ \\
Total egg production (nos.) & - & - & 77037 \\
Mean egg production (nos.) & - & - & $2027 \pm 64$ \\
Total duck meat production $(\mathrm{kg})$ & - & - & 1414.7 \\
Mean duck meat production $(\mathrm{kg})$ & - & - & $37.2 \pm 1.3$
\end{tabular}

Data expressed as mean \pm S.E.

fish species in traditional and composite fish culture practices $(p>0.05)$. However, due to feeding and other management practices, significantly high mean body weight of fishes from April onwards was observed in composite fish culture compared to the traditional practice (Fig. 1). Growth rate of all fishes were found comparatively high in the initial eight months (March-October) (Fig. 1). The total fish productivity was found to be enhanced by 4.8 times in the composite fish culture ponds by adoption of scientific methods of aquaculture.

Economic analyses of the culture operations during the study revealed that at the cost of ₹ 1.8 lakhs, the net profit was ₹4.762 lakhs from 13 ponds covering 1.331 ha water area in one year culture period. Thus, overall benefit/cost $(\mathrm{B} / \mathrm{C})$ ratio from composite fish culture (single component) was found to be 2.64 , which is an indicator of the profitability of the component. This indicates that the investment in composite fish culture is economically viable and on an average ₹1.00 investment brings ₹2.64 returns. Although households have small water bodies (with mean water area of $0.1 \pm 0.03 \mathrm{ha}$ ), the mean annual profit realised by the households under composite fish culture was very high (₹0.366 \pm 0.11 lakh) at

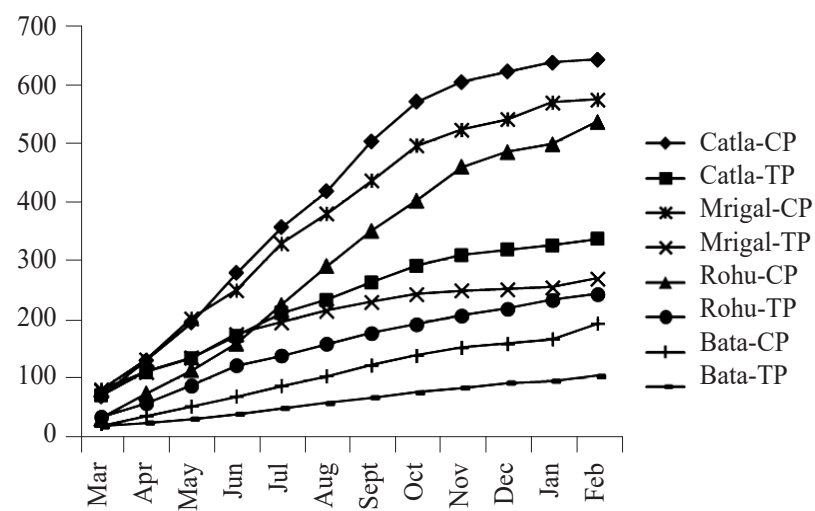

Fig. 1. Temporal increase in mean body weight of different species of fishes in traditional (TP) and composite fish culture practices $(\mathrm{CP})$

the cost of ₹ $0.139 \pm 0.045$ lakh (Table 4), registering a high mean $\mathrm{B} / \mathrm{C}$ ratio of $2.81 \pm 0.10(\mathrm{n}=13)$. This high level of profit can be considered as a significant gain to the income of the households. The operational expenditure of the composite fish culture (single component) comprised of fish seed, feed, net, hapa, lime and inorganic fertilisers. As cow dung was 
Table 4. Economics of traditional practice (TP), composite fish culture (CP) and composite fish culture + duck farming practice $(\mathrm{CP}+\mathrm{DF})$ demonstrated during 2013-14

\begin{tabular}{|c|c|c|c|}
\hline Particulars & $\mathrm{TP}(\mathrm{n}=3)$ & $\mathrm{CP}(\mathrm{n}=13)$ & $\mathrm{CP}+\mathrm{DP}(\mathrm{n}=38)$ \\
\hline \multicolumn{4}{|l|}{ Expenditure (₹ lakhs) } \\
\hline Seed & 0.06893 & 0.36997 & 0.88003 \\
\hline Handi, net and hapa & 0 & 0.14799 & 0.35201 \\
\hline Fish feed@₹18 kg-1 & 0 & 0.98560 & 2.3444 \\
\hline Lime & 0 & 0.01776 & 0.04224 \\
\hline Contingency money & 0 & 0.08879 & 0.21121 \\
\hline Duckling@₹25 duckling ${ }^{-1}$ & 0 & 0 & 0.20 \\
\hline Shade & 0 & 0 & 1.52 \\
\hline Tray & 0 & 0 & 0.095 \\
\hline Duck feed @₹25 kg-1 & 0 & 0 & 0.59 \\
\hline \multicolumn{4}{|l|}{ Transportation cost } \\
\hline i) Fish seed and feed & 0 & 0.08679 & 0.19321 \\
\hline ii) Duckling and duck feed & 0 & 0 & 0.135 \\
\hline Netting charge & 0 & 0.104 & 0.304 \\
\hline Total cumulative expenditure for ' $n$ ' units (A) & 0.06893 & 1.8009 & 6.8671 \\
\hline \multicolumn{4}{|l|}{ Income (₹ lakhs) } \\
\hline Selling of fish in kg@₹110 kg-1 & 293 & 5,966 & 13,947 \\
\hline Eggs 77037 nos. @₹4 piece ${ }^{-1}$ & 0 & 0 & 3.08148 \\
\hline Meat 1414.7kg@₹170 kg-1 & 0 & 0 & 2.40499 \\
\hline Cumulativegross income for ' $n$ ' units (B) & 0.3223 & 6.56262 & 20.82821 \\
\hline Cumulative net return from ' $n$ ' units (B-A) & 0.25337 & 4.76172 & 13.96111 \\
\hline Cumulative $\mathrm{B} / \mathrm{C}$ ratio & 3.68 & 2.64 & 2.03 \\
\hline Mean expenditure (₹ lakhs) & $0.02298 \pm 0.004$ & $0.13853 \pm 0.045$ & $0.18072 \pm 0.01$ \\
\hline Mean gross income (₹ lakhs) & $0.10743 \pm 0.02$ & $0.50482 \pm 0.16$ & $0.54811 \pm 0.04$ \\
\hline Mean net return (₹ lakhs) & $0.08446 \pm 0.01$ & $0.36629 \pm 0.11$ & $0.36739 \pm 0.03$ \\
\hline Mean $\mathrm{B} / \mathrm{C}$ ratio & $3.67 \pm 0.06$ & $2.81 \pm 0.10$ & $1.96 \pm 0.06$ \\
\hline
\end{tabular}

Data expressed as mean \pm S.E.

available in all households, its cost was not considered for calculations.

\section{Duck farming and composite fish culture (multi-component)}

Total fish production was $13.947 \mathrm{t}$ (from 38 beneficiaries' ponds with mean water area of $0.08 \pm 0.008$ ha and mean no. of 270 ducks ha $^{-1}$ ) with a mean productivity of $4.84 \pm 0.09 \mathrm{t} \mathrm{ha}^{-1} \mathrm{yr}^{-1}(\mathrm{n}=38)$. Net fish productivity of $4.25 \mathrm{t} \mathrm{ha}^{-1} \mathrm{yr}^{-1}$ was reported from ponds with 500 ducks $\mathrm{ha}^{-1}$ in Bangladesh without application of fish feed (Latif et al., 2007). In Vietnam, raising of ducks in and on pond increased fish production to an average of $5 \mathrm{t} \mathrm{ha}^{-1} \mathrm{yr}^{-1}$ as against $1 \mathrm{t} \mathrm{ha}^{-1} \mathrm{yr}^{-1}$ without ducks (Delmendo, 1983). In India, demonstration trials have shown a production of over $4 \mathrm{t} \mathrm{ha}^{-1} \mathrm{yr}^{-1}$ (Jhingran and Sharma, 1980) with about 100-150 ducks for a pond having $2 \mathrm{~m}$ water depth. The overall productivity from 38 demonstrated ponds was recorded to be $13947 \mathrm{~kg}$ from 2.963 ha i.e., $4.707 \mathrm{t} \mathrm{ha}^{-1} \mathrm{yr}^{-1}$. Mean fish harvested by the households was $367 \pm 38 \mathrm{~kg}$ during one year culture period (Table 3). The total fish productivity of ponds was found to be enhanced by about 4.96 times through proper feeding of the fishes and maintaining ideal water quality throughout the culture period. The total cost of the experiment was ₹4.328 lakhs and the net profit realised was ₹11.014 lakhs from 38 ponds covering 2.963 ha water area during one year culture period. Thus, overall $\mathrm{B} / \mathrm{C}$ ratio from composite fish culture was found to be high (2.55). In pig-cum fish farming, a net return on per rupee of investment was reported as 2.26 and 1.82 under college farm and village conditions on fish alone (Kujur et al., 2005). In the present study, the mean annual profit realised by individual household under composite fish culture was $₹ 0.29 \pm 0.03$ lakh at the cost of ₹ $0.114 \pm 0.011$ lakh only with the mean $\mathrm{B} / \mathrm{C}$ ratio of $2.53 \pm 0.06$.

The mean duck survival was recorded at $80.32 \pm 1.2 \%$. The mean number of ducklings available for facilitating fertilisation of 1 ha water bodies were 270 (800 in 2.963 ha). 
The number of ducks sufficient to produce manure adequate enough to fertilise 1 ha of water body has been reported in the ranges between 200-400 ducks (Kumar, 1992; FAO, 2001; Shyam and Kumar, 2001). In East European countries, about 300-500 ducks are raised per ha of ponds during summer season (Pillay and Kutty, 2005). Animal wastes lead to increased biological productivity of ponds through various pathways, which in turn lead to increase in fish production (Orhibhabor and Ansa, 2006). However, poorly managed integrated farming systems usually have high nutrient loading leading to development of cyanobacterial bloom (Pearl and Turker, 1995). Therefore, in the present study, the number of ducks were maintained within optimum range. In one year, 200-300 ducks would lay 18000-18500 eggs and would weigh 500-600 kg (live weight) (Shyam and Kumar, 2001). In the present study, the total egg production recorded was 77,037 nos. $\left(26,000\right.$ eggs ha $\left.^{-1}\right)$. The mean number of eggs laid per duck was found to be $187 \pm 2$ in one year in comparison to the average egg production of 237 nos. reported for Khaki Campbell breed as recorded by Latif et al. (2007) and of about 300 eggs or even more as reported by Shyam and Kumar (2001). The mean egg production recorded per unit was $2027 \pm 64$ in one year. Total meat production was $1414.7 \mathrm{~kg}\left(477.5 \mathrm{~kg} \mathrm{ha}^{-1}\right)$. The mean body weight of duck recorded was $2.2 \pm 0.06 \mathrm{~kg}$ and the mean duck meat production per household observed was $37.2 \pm 1.3 \mathrm{~kg}$ (Table 3). Out of the total expenditure of ₹2.54 lakhs in duck farming, the net profit realised was ₹2.947 lakhs from 38 units with $\mathrm{B} / \mathrm{C}$ ratio 1.16 . The mean annual profit realised by individual household under duck farming was $₹ 0.078 \pm 0.004$ lakh at the cost of $₹ 0.067 \pm 0.00$ lakh. Thus duck farming resulted in very thin profit margin with mean $\mathrm{B} / \mathrm{C}$ ratio of $1.16 \pm 0.06(\mathrm{n}=38)$.

During the present study, aquaculture and duck farming together generated high level of profit to the households. By combining both components $(\mathrm{CP}+\mathrm{DP})$ the net profit was ₹13.961 lakhs at the cost of ₹6.867 lakhs from 38 units. The mean annual profit per household was calculated to be $₹ 0.367 \pm 0.031$ lakh at the cost of ₹0.181 \pm 0.011 lakh $(\mathrm{n}=38)$. Thus, the mean $\mathrm{B} / \mathrm{C}$ ratio was $1.96 \pm 0.06$ (Table 4 ). This indicates that the mean annual profit (₹0.366 \pm 0.11 lakh) realised per household from composite fish culture practice (CP) alone in $0.1 \pm 0.03$ ha was equivalent to the profit realised in duck-cum-fish farming $(\mathrm{CP}+\mathrm{DP})(₹ 0.367 \pm 0.031$ lakh) in smaller ponds with mean water area of $0.078 \pm 0.008$ ha due to the incorporation of duck farming as one of the components. The ecological consideration is of paramount importance in integrated fish farming where wastes are recycled (Gabriel et al., 2007). The items produced in integrated farming systems are utilised either as a source of feed, fertiliser or source of additional income (Chen, 1989). In the present study, duck meat and eggs provided additional income and together with no cost for pond fertilisation through duck droppings contributed towards higher economic return of the integrated duck-cum fish farming system $(\mathrm{CP}+\mathrm{DP})$. Compounded duck feed was provided in the initial 3 months of duck farming and in the remaining months, they were fed with locally available ingredients considering that ducks also consumed snails, juvenile frogs, tadpoles, dragon fly larvae as reported by Shyam and Kumar (2001). Pillay and Kutty (2005) also reported that the protein content of supplementary feeds which are necessary to achieve high production rates for ducks can be reduced to 10 or $15 \%$ when the ducks are raised on ponds.

A high $\mathrm{B} / \mathrm{C}$ ratio of 2.70 was reported in integrated poultry-fish-duck farming (Gangwara et al., 2013), whereas in duck-cum-fish farming a low $\mathrm{B} / \mathrm{C}$ ratio of 1.00 was reported with duck feed formulated from locally available ingredients, but without fish feed application (Latif et al., 2007). In the present study, the mean $\mathrm{B} / \mathrm{C}$ ratio in integrated duck-cum-fish farming was found moderate $(1.96 \pm 0.06)$ due to low mean $\mathrm{B} / \mathrm{C}$ ratio of duck farming $(1.16 \pm 0.06)$ and high $\mathrm{B} / \mathrm{C}$ ratio of fish culture (2.53 \pm 0.06$)$.

\section{Fish seed production (single component)}

The FRP hatchery for carp seed production was the first of its kinds in the remote island of Sunderbans. About 5 lakhs spawn were recovered from one cycle of operation of the hatchery and about 1 lakh fingerlings were produced in the rearing ponds. At 2.31 lakh as fixed cost, the net profit gained was 1.69 lakhs from one cycle of operation.

The experimental intervention made by ICAR-CIFA in the Bali Island was taken with an objective to create an alternative aquaculture based livelihood system for the 'Aila' affected people in the Sundarban islands. The demonstration of composite fish culture practice in ponds of selected tribal families registered fish productivity ranging from 4-6 tha ${ }^{-1}$ $\mathrm{yr}^{-1}$ with mean fish productivity of $4.7 \mathrm{t} \mathrm{ha}^{-1} \mathrm{yr}^{-1}$ as compared to less than $1 \mathrm{t} \mathrm{ha}^{-1} \mathrm{yr}^{-1}$ recorded in traditional ponds and thus demonstrated 4.8 times increase in fish productivity. This also resulted in higher profit and income as indicated by high mean $\mathrm{BC}$ ratio $(2.81 \pm 0.10)$ with mean annual profit of $₹ 0.366 \pm 0.11$. It was also inferred that, with this income $67 \%$ of their household requirement was met. Without the interventions, their mean monthly income was ₹0.016 lakh. The mean $\mathrm{B} / \mathrm{C}$ ratio was found highest in traditional practice (3.67 \pm 0.06$)$ due to negligible cost of production but the net income from these practices were very low (₹0.084 lakh only) and thus insufficient to meet the minimum expenditure requirements of the family. Incorporation of two components (fish and duck farming) as alternative livelihood options raised net annual profit of families to ₹ $0.367 \pm 0.03$ lakh. Due to this higher income, the new interventions were able to meet $67 \%$ of the expenditure of the households. The 
Table 5. Economics of carp seed production demonstrated during 2013-14

\begin{tabular}{llll}
\hline Cost of hatchery operation (₹ lakhs) & & Return from 1 cycle (₹ lakhs) & Cost \\
\hline Items & Cost & Items & 4.0 \\
\hline Hatchery & 1.2 & Selling price of 5 lakhs spawn & $(1$ lakh fingerlings \\
Transportation and installation & 0.4 & @ ₹4 piece $\left.{ }^{-1}\right)$ & \\
Shade & 0.4 & & 4.0 \\
Tanks & 0.2 & & 1.69 \\
Pump & 0.04 & & 0.73 \\
Pipes & 0.02 & B) Gross income & Net return from 1 cycle (B-A) \\
Broodstock & 0.05 & B/C ratio & \\
A) Total expenditure & 2.31 & & \\
& & & \\
\hline
\end{tabular}

combination of duck farming and aquaculture was found to be highly beneficial to the households as it helped to raise income in addition to providing nutritionally rich eggs to the households. While fishes were sold in the market in bulk quantities, a significant number of eggs were directly consumed by the households leading to improvement in the nutrition of the households. Demonstration of the successful carp hatchery operations showed the way towards making the island self-sustainable in terms of carp seed production. Just one year of operation of the hatchery generated annual net profit of ₹ 1.69 lakhs and full scale operation is expected to generate much larger income in the future.

Demonstration of aquaculture based livelihoods system in the Bali Island during the present study, has found the way for improving the income, livelihood and nutritional security of the tribal households. Results of the study has clearly demonstrated that aquaculture technologies have the potential in bringing change to the livelihoods through utilisation of the existing resources in the islands of Sundarban. The operational model available in the Bali Island can be replicated in the other islands with similar ecological conditions.

\section{Acknowledgements}

The authors are grateful to the Director General, ICAR, New Delhi; Deputy Director General (Fy.) ICAR, New Delhi; the Wildlife Protection Society of India and Bali Nature Club for their support and help.

\section{References}

APHA 1998. Standard methods for the examination of water and wastewater, American Public Health Association, Washington DC, USA.

Bag, N., Moulick, S. and Mal, B. C. 2014. Economic feasibility of intensive aquaculture integrated with irrigation system. Indian J. Fish., 61(4): 72-78.
Bhattacharya, A. K., Jha, S. and Dave, A. 2001. Biodiversity conservation and ecotourism, lessons from Sundarban tiger reserve. Van Vigyan-Jour for Sci. 39: 73-81.

Bhattacharya, S. 1998. Sundarban - Dying a slow death. The Hindu Survey of Environment, p. 89-94.

Chakrabarti, P. P., Chattopadhyay, D. N., Mandal, R. N., Mohapatra, B. C., Kumar, K., Mitra, S., Ghosh, A. and Jayasankar, P. 2013. Aquaculture development plan for Aila affected Bali Island of Sundarban - a study through participatory rural appraisal. Central Institute of Freshwater Aquaculture (ICAR), Bhubaneswar, p. 1-40.

Chattopadhyay, S. S. 2003. An ecosystem in Peril. Frontline, 20: $45-48$.

Chaudhuri, A. B. and Choudhury, A. 1994. Mangroves of the Sundarbans. In: Zakir Hussain, M. and Acharya, G. (Eds.): IUCN- The World Conservation Union, Bangkok, Thailand.

Chaudhuri, A. B. 2007. Biodiversity of mangroves. Daya Publishing House, New Delhi, 332 pp.

Chen, F. Y. 1989. Chicken farming in integrated fish farming. Regional Aquaculture Center, Wuxi China. NACA Technical Manual, 11: 4-30.

CIFA 2004. Portable FRP carp hatchery. In: CIFA Technologies. Central Institute of Freshwater Aquaculture (ICAR), Bhubaneswar, p. 22-23.

Delmendo, M. N. 1983. Integrated farming systems in Asia and the Pacific. In: FAO Report of the Expert Consultation on the Development of Integrated and mixed farming systems and water conservancies in rainfed areas. Bangkok, Thailand (RAS/81/044) 2: 63-84.

Delmendo, M. N. 1983. Integrated farming systems in Asia and the Pacific. In: FAO Report of the Expert Consultation on the Development of Integrated and mixed farming systems and water conservancies in rainfed areas. Bangkok, Thailand (RAS/81/044) 2: 63-84.

FAO 2001. Integrated fish-duck farming. In: Integrated agricultureaquaculture: A primer. FAO Fisheries Technical Paper No. 407, FAO, Rome. 
Hazra, S., Ghosh, T., Dasgupta, R. and Sen, G. 2002. Sea level and associated changes in the Sundarbans. Sci. cult., 68(9-12): 309-321.

HDRCC 2009. District human development report - South 24 parganas. Development and Planning Department, Govt. of West Bengal, p. 1-311.

Gabriel, U. U., Akinrotimi, O. A., Bekibele, D. O., Anyanwu, P. E. and Onunkwo, D. N. 2007. Economic benefit and ecological efficiency of integrated fish farming in Nigeria. Sci. Res. Essays, 2(8): 302-308

Gangwara, L. S., Saran, S. and Kumar, S. 2013. Integrated poultry-fish farming systems for sustainable rural livelihood security in Kumaon Hills of Uttarakhand. Agr. Econ. Res. Rev., 26: 181-188.

Jhingran, V. G. and Sharma, B. K. 1980. Fish-cum-livestock farming in India. Proceedings of the ICLARM Conference on Integrated Aquaculture-Agriculture Farming Systems No. 4.

Kujur, N., Prasad, C. M., Singh, A. K. and Singh, S. K. 2005. Economic analysis of integrated pig-cum-fish farming in Jharkhand. Indian J. Anim. Res., 39(1): 73-75.

Kumar, D. 1992. Fish culture in undrainable ponds: A manual for extension. FAO Fisheries Technical Paper No. 325. FAO Food and Agriculture Organisation of the United Nations, Rome. 239 pp.

Latif, M. A., Alam, M. J. and Rahman, M. A. 2007. Integrated duck-cum-fish farming in Bangladesh. J. World Aquac. Soc., 24(3): 402-409.
Mohanty, B. B., Mal, B. C., Sharma, K. K. and Mohapatra, B. C. 2009. Water requirements of a portable FRP carp hatchery - for rohu spawning and eggs hatching. Fishing Chimes, 29(5): 47-49.

Mohapatra, B. C., Sarkar, B., Singh, S. K. and Majhi, D. 2007. FRP Carp hatchery and its economics. Workshop on Portable hatchery for better carp seed production. Central Institute of Freshwater Aquaculture, Kausalyaganga, Bhubaneswar, Orissa, India. p. 11-18.

Mohapatra, B. C., Sarkar, B. and Sarangi, N. 2008. Portable FRP carp hatchery technology - successful adoption in India. Fishing Chimes, 28(4): 48-52.

Mohapatra, B. C., Singh, S. K., Sarkar, B. and Sarangi, N. 2005. Portable FRP carp hatchery: An aid for rural aquaculture. Proceedings of the International Conference on Plasticulture and Precision Farming, November 17-21, New Delhi, India, p. $515-522$

Oribhabor, B. J. and Ansa, E. J. 2006. Organic waste reclamation, recycling and re-use in integrated fish farming in the Niger Delta. J. Appl. Sci. Environ. Mgt., 10(3): 47-53.

Pearl, H. W. and Tucker, O. S. 1995. Ecology of blue green algae in aquaculture ponds. J. World Aquac. Soc., 26(2): 109-131.

Pillay, T. V. R. and Kutty, M. N. 2005. Integration of aquaculture with crop and livestock farming. In: Aquaculture: Principles and practices. Blackwell Publishing Ltd., p. 579-582.

Shyam, R. and Kumar, K. 2001. Duck-fish integration. In: Fish-livestock integrated farming. Central Institute of Freshwater Aquaculture (ICAR), Bhubaneswar, p. 16-24. 